\title{
EL IRRACIONALISMO EN EL OJO DE LA AGUJA DE CARLOS BOUSOÑO: PALABRAS DE UN REINO QUE NO ES DE ESTE MUNDO
}

Dora Sales Salvador

Universidad Jaume I de Castellón

RESUMEN

Carlos Bousoño no sólo crea poesía, sino que también reflexiona crítica y teóricamente sobre ella. En este trabajo, analizamos uno de los últimos poemarios del autor, El ojo de la aguja (1993), donde el poeta -desde la plenitud lírica-se muestra fiel a su temática habitual, su «primavera de la muerte». Con todo, nuestro interés se centra en la articulación de los elementos irracionales presentes en esta colección, para lo cual acudimos a las propuestas que el propio Bousoño plantea en Teoría de la expresión poética (1952) y El irracionalismo poético (el símbolo) (1977).

\section{APUNTES INTRODUCTORIOS ${ }^{1}$}

En referencia a la persona del poeta, crítico y teórico Carlos Bousoño diremos que nace en Boal (Asturias) en 1923. Pronto, a los diez años, pier-

1 La información biográfica y bibliográfica sobre Carlos Bousoño proviene de diversas fuentes. Véanse Fotuño Llorens (1992) y Bousoño (1980). 
de a su madre. Su padre marcha a México, ${ }^{2}$ con lo que vive una adolescencia solitaria que tal vez motivase una precoz vocación poética. Se traslada a Madrid en 1943, donde se licencia, y posteriormente se doctora, en Filología Románica, ejerciendo como profesor universitario en la Universidad Complutense de Madrid desde 1950. Además de su faceta creadora, es relevante su labor de crítico literario, desde Teoría de la expresión poética (1952), hasta Épocas literarias y evolución (1981). Por el primero de estos estudios obtuvo el Premio Fastenrath de la Real Academia de la Lengua. En dos ocasiones ha recibido el Premio Nacional, una en 1978 por el ensayo $E l$ irracionalismo poético, y otra en 1989 por el libro de poemas Metáfora del desafuero. Es Premio de la Crítica en 1979 por sus volúmenes poemáticos Oda en la ceniza y Las monedas contra la losa. En 1993 le fue otorgado el Premio Nacional de las Letras. Desde 1979 es miembro de la Real Academia Española de la Lengua, habiendo recibido también el Premio Príncipe de Asturias.

La bibliografía poética de Bousoño es extensa ${ }^{3}$. El ojo de la aguja $(1993)^{4}$ es su octava colección de poemas, la última hasta hace muy poco 5 . Localicemos la obra a tratar en la trayectoria de su autor, que por un lado presenta una constante y por otro una constante evolución. Así, la constante en la obra de Carlos Bousoño en su cosmovisión, reflejada en su temática. El poeta se mantiene fiel a los temas que propuso en sus primeras obras, fundamentalmente el amor a la vida, aunque precaria y falaz; la visión paradójica de la realidad, gratificante y cruel a un mismo tiempo, y el contraste entre el exultante ser del hombre y su inevitable caída hacia la nada. ${ }^{6} \mathrm{Con}$ todo, la personal cosmovisión de Bosuoño se resume espléndidamente en sus propias palabras: la vida como «primavera de la muerte». Es esta expresión, según el propio poeta, «la que mejor puede incorporar la intuición que perdurablemente se halla al fondo de mi vida y no sólo de mi poesía» (BouSoño, 1980: 19).

Pero sí, temáticamente, Bousoño es fiel, estilística y formalmente, es profundamente evolutivo. El irracionalismo, la ampulosidad y la prolijidad, en pa-

2 País en el que él mismo también reside entre 1946 y 1948.

${ }^{3}$ De forma resumida: Subida al amor (1943), Primavera de la muerte (1946), Noche del sentido (1957), Invasión de la realidad (1962), Oda en la ceniza (1967), Las monedas contra la losa (1973), Antología poética (1945-1973) (1976), Selección de mis versos (1980), Metáfora del desafuero (1988), el ojo de la aguja (1993).

4 En el presente trabajo, seguimos la edición de 1993. En todas las citas del poemario, la paginación indicada entre paréntesis se refiere a dicha edición. Véase Bousoño (1993).

5 Acaba de publicarse El martillo en el yunque (1997), Santander: Argoma.

6 Véase ForTuÑo LloRens (1995: 19). 
labras de Fortuño Llorens, va aumentando paulatinamente, hasta llegar a El ojo de la aguja, «iluminado de trascendencia».

El propio Bousoño, en su clarificador prólogo a Selección de mis versos, explica su mutación estilística, nacida a raíz de los libros Oda en la ceniza y Monedas contra la losa. El poeta reconoce que en Invasión de la realidad había llegado al reconocimiento del mundo como hermosura de incesante sorpresa y maravilla, con lo que su propósito postrero iba a ser precisamente, como lógica consecuencia, buscar un estilo renovado que fuese capaz de reflejar esa experiencia de brillantez y sorpresa.

Escuchemos al autor:

«De pronto, ahora, el poema se originaba de otro modo: aparecía el verso movido en mí desde una noción capaz, en algún sentido, de producir sorpresa; una noción, a veces, especialmente paradójica, que podía ser una simple idea, pero que las más de las veces consistía en una metáfora o en un símbolo» (Bousoño, 1980: 25-26).

Con todo, el lector, si la intención estética de Bousoño se cumpliese, no podría sino sentirse sobresaltado, maravillado ante la palabra poética. En definitiva, se trata ante todo de «proporcionar al lector un incesante deslumbramiento semejante al que yo sentía frente al mundo» (Bousoño, 1980: 26). Así, Bousoño aspiraba a que su estilo poético fuera realmente una «primavera de la muerte».

Es en este contexto donde tendríamos que ubicar El ojo de la aguja, en esta etapa del deslumbramiento y la palabra mágica, sorprendente y sorprendedora ${ }^{7}$. Fortuño Llorens (1995) habla, sin embargo, de una doble sensación: «continuidad desconcertadora». En su evolución formal, en su intento por deslumbrar y mostrar la belleza de la palabra poética en todo su esplendor, Bousoño llega a la trascendencia, a la glorificación, a la emocionalidad suprema. El mensaje primordial que este volumen poemático de Bousoño nos transmite es, como bien dice Fortuño Llorens (1995), la salvación por la palabra ante la desesperanza del hombre, «la nada siendo», en palabras del poeta. Una salvación que Bousoño, tocado por la poesía, como diría Neruda, pretende compartir con nosotros mediante su creación artística.

7 Etapa que según el propio Bousoño confiesa, constituye el tercer ciclo en su evolución estilística. Véase Bousoño (1980). 
ELEMENTOS IRRACIONALISTAS EN EL OJO DE LA AGUJA ${ }^{8}$
«El poeta no quiere decir nada, tan sólo quiere expresar una emo- ción» (Carlos Bousoño). ${ }^{9}$

Como hemos avanzado en la previa introducción, El ojo de la aguja se halla enmarcado en la etapa del deslumbramiento en la poesía de Carlos Bousoño. $Y$ es que, ciertamente, la multitud de elementos irracionalistas que plagan cada uno de los poemas del libro llegan a maravillar, a deslumbrar al lector, hasta el punto de que éste cree estar, por momentos, inmerso en un ciclón de sentimientos y emociones sin fin.

Al tratar sus temas preferidos, como son el misterio que rodea la vida del hombre, la llegada inexorable de la vejez, las ansias frustradas de trascendencia, el amor en exaltación dionisíaca y como ciencia de saborear la vida, en palabras de Fortuño Llorens (1995), el tránsito angosto de la vida a la muerte y el enigma del Más Allá, Bousoño deja volar libremente su imaginación y juega con sus palabras, que en definitiva, son sus emociones. Y así, aunque retoma y prosigue con la temática que ha ocupado toda su poesía, se centra especialmente en la vivencia de la muerte.

De hecho, en su «Introduccion», ${ }^{10}$ ya establece un pacto con el lector, por el que constata ese «saber que voy a morir» (p. 17) que da alas a su imaginación, elemento que, de entrada, es de suma importancia para Bousoño, quien confiesa «una innata tendencia mía al vuelo de la imaginación» (Bousoño, 1980: 29).

En la primera parte de El ojo de la aguja, el poeta trata, desde el irracionalismo poemático, todos los temas que le interesan y le persiguen desde la génesis de su actividad creadora. Pero es la segunda parte, titulada genéricamente «Canto de Salvación», la que supone mayor novedad y trascendencia. Lo relevante de este «Canto» es su mensaje definitorio: el hecho de que la salvación ante la angustia existencial y metafísica puede llegar mediante la belleza de la palabra poética.

Los elementos de cariz visionario o irracionalista que definen la poesía de Bousoño y que alcanzan su máximo esplendor en este libro, pueden llegar a producir desconcierto y extrañamiento. Así, como afirma Fortuño Llorens: «En

${ }^{8}$ En cuanto a la terminología empleada, seguimos las teorfas del propio Bousoño: Teorfa de la expresión poética (1952) y El irracionalismo poético (el símbolo) (1977).

9 Palabras pronunciadas por el poeta en el transcurso de una conferencia ofrecida en la Universidad Internacional Menéndez Pelayo de Valencia el 19 de septiembre de 1996. Véase BousoÑo (1996).

10 En el poema «Definiendo la imaginación». 
muchas ocasiones, es el conjunto del poema el que nos da su sentido, tras la minuciosidad, detallismo y prolijidad que producen inicial desconcierto» (Fortuño Llorens, 1995: 20).

La sucesión de imágenes visionarias, visiones, símbolos, desplazamientos calificativos, sinestesias, antítesis y demás elementos irracionalistas caracterizan el lenguaje poético, ensimismado y emocional, del presente libro. Las asociaciones que realiza el poeta, de tan emocionales y preconscientes, llegan a semejar oníricas, irreales. Con El ojo de la aguja nos hallamos ante una de las últimas entregas poemáticas de un autor ya en la cúspide de su proceso creador, donde las visiones, imágenes visionarias y demás elementos irracionalistas se adueñan por completo del lenguaje.

Ante todo, las visiones irracionalistas del creador caracterizan este volumen poemático, tal vez, diremos, como consecuencia del elevado límite de irracionalidad y emocionalidad al que Bousoño asciende en este libro, lo que él mismo denominaría, teóricamente, irracionalismo fuerte.

Mediante esta poesía visionaria, compuesta en la vejez, Bousoño expresa unas emociones que muestran cómo el poeta siente, más que nunca, esa vivencia de la muerte que ha estado presente en toda su obra, pero que aquí cobra mayor fuerza. Desde su momento presente, desde su tiempo del «saber que voy a morir», Bousoño intenta, con la poesía, a través del tiempo de la vida en el arte, vislumbrar el tiempo del Más Allá, el que se halla tras la muralla, tras esos «muros de sueño y cal» (p. 37) que sólo la imaginación y la emoción pueden salvar. Un tiempo enigmático, misterioso $\mathrm{y}$, sin embargo, cada vez más cercano, que el poeta imagina y sueña en sus poemas, sus emociones sobre el papel.

De este modo, en la epístola inicial, en la que ya se establece un pacto de lectura, el autor nos ofrece una idea acerca del ambiente de irrealismo que define al texto. En este punto inicial de la obra, Bousoño habla ya de los tres tiempos que van a tener cabida en la colección poemática: el tiempo de la vida en la vida, el real; el tiempo de la vida en el arte, que tiene la facultad de transformar nuestra visión de la realidad; y el tiempo de la vida en un Más Allá enigmático y desconocido, un tiempo que el poeta sueña e imagina mediante la palabra poética.

Con todo, los recursos de índole irracionalista se suceden sin pausa en los poemas que componen El ojo de la aguja, donde ante todo nos hallamos ante una primacía de la visión ", quizás como consecuencia del alto grado de irracionalismo al que llega el lenguaje poemático. Así, por ejemplo, el poema «Lo-

"Recordemos, dada la radical importancia de este recurso en la obra tratada en el presente trabajo, cómo en su Teoría de la expresión poética (1952: 232, vol. I), Bousoño definía la visión como una imagen irracional y subjetiva en la que ya no hay esfera de realidad, sino atribución de cualidades o de funciones imposibles a un objeto. 
gogrifos», en el que Bousoño constata el paso de lo humano por el ojo de la aguja, que representa el «angosto tránsito humano», en palabras de Fortuño Llorens (1995), podría ser considerado prácticamente en su totalidad como una visión del poeta, quien considera en este punto el tiempo de la vida en la vida, pero siempre en tránsito hacia el tiempo del Más Allá, inexorable. Desde la 6ptica de Bousoño, la vida humana es, ante todo, un misterio, un logogrifo, en cualquier lugar, incluso debajo de los puentes, incapaces ya de proteger: «pues no hay puente y morimos/-y el ojo de la aguja que está en ti-》 (p. 28).

En el poema «La muralla», Bousoño también reflexiona sobre ese ámbito del espacio entre dos mundos, dos tiempos, uno conocido $\mathrm{y}$, aún así, a veces incomprensible, y el otro por conocer, soñado. «La muralla» es, en palabras del poeta, «el muro que aparta la interminabilidad de nuestro ser» (p. 33), es ese paso último que separa la vida de la muerte. En esta composición, Bousoño se ensimisma y se emociona de forma sublime con la palabra poética, en un auténtico crescendo de lo irracional:

\section{«(...);Oh tú, primavera extraña, con un raro aroma a más que invade los corazones! ¿Fresco Dios que no es azar!(...)” (p. 36).}

Sin embargo, pese a esa «piedra enorme del deseo» (p. 37), hallamos los «muros de sueño y cal» (p. 37) que, en definitiva, representan una toma de contacto con el mundo real, tras la emoción de la palabra poética. «La muralla» nos muestra las ansias frustradas de trascendencia, que, sin embargo, sí han hallado refugio emocional en el irracionalismo visionario presente en el lenguaje.

En otro poema definido por las visiones, «La madeja», Bousoño se refiere de manera sensible al sentimiento que le produce el tiempo enigmático y desconocido del Más Allá, «el laberinto, el otro lado» (p. 55), que él considera como «la madeja que no se puede desenredar» (p. 55). A lo largo de este poema, el creador plantea una serie de preguntas sin respuesta («por qué estamos aquí» (p. 56)), como suprema representación de la imposibilidad de conocer ese tiempo que se halla más allá de la vida, y del miedo a ese algo desconocido que llegará, inevitablemente. El poeta se siente como un cojo que mira desde el sitio de una lágrima» (p. 56), asustado por la madeja, el laberinto desconocido. Quizás, precisamente por la imposibilidad de saber representada en esta composición, Bousoño no le puede colocar un punto final a la misma, sino puntos supensivos ${ }^{12}$, en un fin que no es tal, abierto, irresoluto.

12 De hecho, tendramos que resaltar el uso reiterado de los puntos suspensivos, con funciones diferentes, según veremos más adelante, a lo largo del poemario. 
Con los anteriores ejemplos, hemos constatado la importancia fundamental y definitoria del uso del recurso irracionalista de la visión en este libro. No hemos pretendido plantear todos los casos, lo que resultaría prácticamente inagotable en esta obra, sino reflexionar acerca de aquellos poemas en los que este elemento visionario nos ha parecido paradigmático.

Sin embargo, en El ojo de la aguja no son todo visiones. Hay más, mucho más. Las antítesis y paradojas son otro de los recursos más empleados. «Todo pasa y todo queda» (p. 17), como dice el poeta ya al inicio, en «Definiendo la imaginación». Bousoño, en su intento por comprender aquello que es incomprensible, como es el paso de la vida a la muerte y el desconocido después en el Más Allá, en esa frustración por conocer que lleva a la emoción de la palabra poética, siente que cada paso hacia delante constituye también un paso hacia atrás, como si se tratara de «un venir para un cesar» (p. 36), una «explosión de ese moverse y de esa inmovilidad» (p. 36), como dice en «La muralla». $O$ quizás, lo que ocurre es, como afirma en «El canto», que «estamos viendo al dejar de ver» (p. 130).

Sin embargo, el poema que ejemplifica de forma más clarificadora el uso de las antítesis y paradojas es «Igualdad», donde se reconoce que en definitiva «Ignoras y sabes./(Ignorar, que es nada. Saber, que no es más)» (p. 49). Así se siente el poeta ante esa madeja desconcertante que no puede desenrollar.

Ante ese caos del no saber, Bousoño siente que la palabra es la única salvación, la palabra poética, la palabra sensiblemente sentida, la palabra encarnada, con la que escribe emociones desde lo más hondo. Así, en «Escribiendo», esa realidad del desconocimiento se ve sustituida por otra, que produce y que gratifica, gracias a la cual, paradójicamente, «el dolor es feliz» (p. 124), y hablamos del «señorío de la levedad» (p. 130) y de la «consagración de la supremacía de la nada» (p. 130). Todo para que en el «Canto a los tres tiempos», «brille la realidad oscuramente/en la calleja tortuosa y sucia» (p. 145).

Las imágenes visionarias, puesto que no podía ser de otra manera, también ocupan un lugar destacado en la configuración irracionalista de este libro: «dos amantes encarnizados, vivir y morir» (p. 21), «el mar marmóreo y retumbante, en donde mueren, aturdidas y congeladas, las blancas gaviotas de la resurrección» (p. 40), «[vidas] suficientemente arañadas, pisadas, vaciadas, extintas» (p. 44), «esta tarde casi inmóvil, pura» (p. 63), «resbala en el papel el tiempo puro de rosas y jazmines» (p. 147), por poner tan sólo unos ejemplos. Son estas imágenes visionarias sugerentes, emotivas metáforas en las que nos hallamos ante sensaciones por las cuales los elementos aparecen adjetivados por términos fuertes, definitorios, inequívocos: encarnizados, marmoreo, retumbante, aturdidas, congeladas, arañadas, pisadas, vaciadas, extintas, puro, entre otros muchos. 
La visión sinestésica no deja de aparecer en este poemario. Así, el poeta habla, por ejemplo, de «la noche dificil o el arduo pinar» (p. 51), «un viento triste se lleva hojas y flores» (p. 89), o de «una luz amarilla, feliz, en que el dolor brilla» (p. 117). Es la emoción y lo que ésta produce en el poeta, lo que le lleva a atribuir cualidades de manera irracional. De este modo, Bousoño puede hablar de una noche difícil, un viento triste y una luz feliz. Puede hacerlo así porque así lo siente. Para él, emocionalmente, ésos son los adjetivos adecuados, aunque al lector le puedan provocar, en principio, un desconcierto racional. Ante todo, deberíamos recordar que la lectura de Bousoño precisa ser realizada desde el ámbito de la emoción, no desde la razón.

Los desplazamientos calificativos también colaboran en la configuración de todo este irracionalismo emocional en la poesía bousoñiana: «un hilo plateado/que va entrando en la aguja» (p. 27), «tersa brisa/dando frescor al mar, que, interminable/existe por completo y por completo es/y así hace envejecer de manera instantánea/al rostro humano que lo mira» (p. 77), «para que tú ascendiéses a un perdonar maduro/que como fruta lenta fue aromándose» (p. 79), entre otros, muestran como el poeta atribuye cualidades atendiendo a su impresión subjetiva, connotativa, sensible.

La superposiciones constituyen un elemento que, aparte de la metáfora, también aportan irracionalidad a esta obra. Aunque la superposición puede ser de tipo metafórico, espacial, significacional, situacional o temporal, en la obra de Bousoño predominan las superposiciones de este último tipo, las temporales, aquéllas en las que el tiempo de la vida en la vida, el tiempo de la vida en el arte y el de la vida en el Más Allá, llegan a simultanearse, «desde siempre hasta siempre» (p. 23). Y es que en la poesía bousoñiana el concepto de tiempo es diverso. La superposición temporal de la que estamos hablando podría sugerir la idea de una concepción mítica del tiempo, pero en realidad, Bousoño tiene una concepción más bien genérica del mismo. Aunque $E l$ ojo de la aguja comience precisamente con la distinción de tres tiempos, en realidad todos ellos vienen a configurar uno solo, el Tiempo, visto desde diferentes ángulos. Quizás, la finalidad de esta concepción genérica sea, como el propio Bousoño afirma en su Teoría de la expresión poética, la de «mostrar hasta qué punto sentimos la vida como patética bravedad» (Bousoño, 1952: 406).

Para ejemplificar el uso de esta superposición temporal, consideremos brevemente el poema «La muralla», en el que el poeta, desde su tiempo de la vida en la vida, y también de la vida en el arte, pensemos que está poetizando, medita acerca del otro tiempo, el de la vida en el Más Allá. De este modo, observamos simultáneamente los tres tiempos en un mismo poema. Esa brevedad a la que aludíamos queda claramente reflejada, desde esta vida, desde este 
tiempo, $\tan$ pasajero, tan cercano en realidad al otro, y a la vez, $\tan$ frustrante, tan falaz, tan imposibilitado para vislumbrar lo que se halla tras la muralla:

\author{
"iMuralla-del-pronto-iré. \\ pared-del-dolor-no-habrá, \\ catástrofe destructora \\ de un venir para un cesar» (p. 36).
}

Los símbolos son un recurso que consideramos menos empleado en este libro, aunque no por ello dejan de hacer acto de presencia, siendo los más interesantes los que hallamos en el poema «Testamento»: «hijo mío, mi roedor, mi insaciable desposeedor, raedor» (p. 100), «Tú y yo, pájaros que vuelan todavía al unísono procesional» (p. 101). Las ideas del legado transmitido, roído según el poeta, y la libertad unificadora, definen estos símbolos.

Aparte de los elementos de carácter irracional o visionario que hemos comentado y que realmente vertebran la poesía de Carlos Bousoño, en El ojo de la aguja también hallamos otros recursos que merecen ser destacados por la frecuencia con la que aparecen. Hablemos en primer lugar del uso reiterado de los puntos suspensivos. Según Fortuño Llorens:

«El desajustado texto simboliza doblemente su propia actitud de confusión y desconcierto ante el mundo y de un marcado escepticismo revelado en sus expresiones y en los finales poemáticos abiertos (uso reiterante de los puntos suspensivos) y sugerentes, que solicitan la correflexión del lector (...)» (Fortuño Llorens, 1995: 20).

Así, los puntos suspensivos, que el poeta emplea con asiduidad, suponen en varias composiciones esos finales abiertos de los que habla Fortuño Llorens, finales que hallamos en «La vejez», «La madeja», «Soplar», «Sala quirúrgica» ${ }^{13}$, «Salvación en la lentitud», «Oración inicial del adivino», «Poeta en un abordaje con el mar en calma», «Palabras vivas», «Canto de los tres tiempos» y «La transfiguración».

Por otro lado, opinamos que cuando los puntos suspensivos surgen en cualquier lugar de la composición, suponen momentos de silencio por parte de la voz poética, tal vez momentos en los que la emoción irracional es tanta que ni siquiera puede ser verbalizada:

1.3 Poema que también comienza con puntos suspensivos: «... Y entraba en el silencio» (p. 59). 


\author{
«Días venidos, idos... \\ ¿Quién los trazó iracundo \\ con los dedos heridos?» (p. 73) \\ «(...) los ojos te arrancó. \\ Y la paz se extendía por la noche profunda» (p. 80) \\ «la mina honda del vivir \\ sin sueño: vida, que, en todo instante, \\ es cual boca de lobo, ademán en la sombra...” (p. 123)
}

El empleo de expresiones coloquiales también resulta significativo, por cuanto aporta naturalidad a una poesía irracional y visionaria que usualmente se aleja de «las palabras de la tribu». Consideremos algunos ejemplos: «no sé bien», «quién sabe» (p. 22), «pero mira por dónde» (p. 23), «dejémoslo así» (p. 39), "y es que algo», «y resulta entonces» (p. 40), «Y luego, ¿qué es lo que queda?» (p. 119).

En definitiva, tal y como el propio Bousoño afirma:

«Y es que el verbo ha nacido y habita entre nosotros

con naturalidad: taller, viruta, escoplo, martillo, sierra, clavo.

Barro en manos del alfarero,

sencillas las palabras, las de todos los días (...)» (p. 121)

Es la emoción poética la que hace uso de las palabras, «palabras vivas» dice el poeta, y las aleja del habla cotidiana, trascendiéndola, sublimándola, en definitiva, poetizándola, con «la mano en el papel. Intensamente» (p. 123).

Como hemos podido comprobar, el empleo de elementos irracionalistas, que en general hacen que primen la sugerencia y la alusión sobre el detalle concreto, que pierde relevancia, da forma y significado a la poesía de Bousoño, visionaria, pero profundamente humana, fruto de la reflexion de un hombre ante su propia vida y sus dudas existenciales. Por otro lado, si bien es cierto que los recursos de carácter irracional se hallan en la génesis del lenguaje poético empleado a lo largo de todo el libro, podríamos localizar el clímax del poemario en «allá, en la felicidad, en el auge» ${ }^{14}$, donde lo irracional llega hasta lo más alto, en un poema en el que Bousoño defiende el grafé poético como salvación, como festividad:

14 Segunda parte de «El canto». 
" $i$ es aquello la entusiasta festividad y los vítores

del crecer y el pujar en todas las direcciones, (...)

parece aquello también como una gozosa

celebración en la que se ponen banderas

en todos los balcones de todas las casas (...)m (pp. 135-36)

Es en el momento de la escritura poética, cuando «resbala en el papel el tiempo puro de rosas y jazmines" y las palabras reflejan emociones y sentimientos de un reino que ya no es tan sólo de este mundo, cuando el poeta se siente seguro, libre, puro ser humano.

\section{A MODO DE CONCLUSIÓN}

El ojo de la aguja representa en la obra de Carlos Bousoño un acercamiento del Bousoño poeta al Bousoño teórico, sobre todo en la segunda parte del poemario, «Canto de salvación», de la que Fortuño Llorens afirma que es: «Metapoética en cuanto continúa con sus disquisiciones sobre el lenguaje poético completando su amplio quehacer de teórico de la literatura» (Fortuño Llorens, 1995: 20).

De hecho, los cinco primeros poemas de este «Canto de salvación» constituyen un auténtico tratado de poética. Cada una de las cinco composiciones expone un rasgo del habla poética. En «Desviándose de las palabras de la tribu» reitera su consideración del lenguaje de la poesía como una desviación de la norma fijada por la lengua, quizás como una expresión de libertad creadora ${ }^{15}$. En «Concierto de flauto o el rico y el camello» constata el poder transfigurador y de extrañamiento que esa desviación puede producir. En los poemas «Poeta en un abordaje con el mar en calma» y «Palabras vivas», nos habla de la belleza creada por el lenguaje poético y su persistencia. Así, las palabras se hallan «instaladas en la permanencia» (p. 121), en nuestra realidad, mediante la poesía y su belleza. Finalmente, en «Escribiendo», el habla poética se define como salvación, sustituyendo a una realidad que no es agradable, una realidad que la poesía dulcifica, suaviza y sublima, porque «(...) ha empezado a brotar/algo encendido y dulce» (p. 123).

is En este punto, nos gustaría mencionar a modo de anécdota la siguiente afirmación del lingüista EugEnIo COSERIU, realizada en el transcurso de una mesa redonda en torno a la traducción. a la que COSEIRU asistió en la Universidad Internacional Menéndez Pelayo de Valencia el 13 de septiembre de 1994: «El lenguaje poetico no es una desviación del lenguaje normal, sino el lenguaje normal en su plenitud» (Coseriu, 1994). 
El propio Bousoño explica el siguiente modo el desarrollo por Oda en la ceniza, Las monedas contra la losa, y continuado por El ojo de la aguja: ${ }^{16}$

«(...) sólo hacia los cuarenta años mi tendencia analítica se juntó definitivamente a mi capacidad emotiva, y el encuentro o soldadura de una mitad y otra de mi ser produjo como resultado, a partir de Oda en la ceniza, un nuevo estilo en el que un lector curioso podría reconocer, en el poeta que escribía sus versos con intención puramente poética, al teórico y crítico que forjaba sus tesis racionales con intención puramente doctrinal» (Bousoño, 1980: 27).

$\mathrm{Y}$ es que, en definitiva, Bousoño poeta y Bousoño teórico son un mismo hombre, por lo que esta evolución estilística, este acercamiento entre la teoría y la práctica, a través de la libertad otorgada al empleo de elementos irracionales, es, ante todo, una consecuencia de carácter lógico. Una consecuencia que hace posible que este último estilo del poeta refleje, en sus propias palabras, «con mayor fidelidad que antes al hombre que soy» (Bousoño, 1980: 29). En la evolución, en la búsqueda del estilo propio y del habla poética que expresa emociones y sentimientos, el poeta también se ha hallado a sí mismo. Así, la irracionalidad, más que un modo de huir hacia lo irreal, se vería como un modo nuevo de considerar la realidad del hombre, desde la emoción preconsciente, esencialmente humana.

En El ojo de la aguja, Bousoño plantea ante todo la idea de la salvación por la palabra, la palabra poética, que se muestra, pues, como la palabra redentora. El propio Bousoño afirma:

«El arte y la poesía son melancólicos sustitutivos de Dios. Así, concibo la poesía como una sustitución de un ser supremo que nos salve» (Bousoño, 1993).

Quizás, desde su vejez, desde su ya real cercanía a la muerte, Bousoño, poeta y teórico, sin que la distinción importe realmente, transmite en su obra una serenidad tranquilizadora acerca de ese tiempo del Más Allá, considerando desde este tiempo de la vida en la vida, este tiempo de la vida en el arte. Así, desde su cercanía, lúcida, serena, intensa y exaltada por la poesía y su belleza, el poeta es más capaz que nunca de hablar de su fiel cosmovisión, su «prima-

${ }^{16}$ Continuidad que, tal vez, se halla también en su último poemario, El martillo en el yunque. 
vera de la muerte». Por todo ello, afirma el poeta en referencia a El ojo de la aguja: ${ }^{17}$

"Yo soy un estoico a quien no le da miedo la muerte. Vivo su cercanía intensamente, pero no desesperación» (Bousoño, 1993).

Así, desde esa posición privilegiada, Bousoño nos regala, generosamente, su poesía irracionalista, poesía plena, emocionada.

\section{BIBLIOGRAFIA}

Bousoño, Carlos (1952). Teoría de la expresión poética. Madrid: Gredos, 1976 , 2 vols.

- (1977). El irracionalismo poético (El símbolo). Madrid: Gredos.

- (1980). Prólogo. Selección de mis versos. Edición del autor. Madrid: Cátedra, pp. 13-31.

- (1993). El ojo de la aguja. Barcelona: Tusquets, Nuevos Textos Sagrados.

- (1996). Conferencia de Clausura. «Sentido y situación de la poesía en los años 50: Francisco Brines y Claudio Rodríguez». La escritura poética de los 50: historia y sistema de un grupo generacional. Valencia, 19 de septiembre de 1996.

Coseriu, Eugenio (1994). Mesa redonda. «Práctica de la traducción literaria.» Traducción y contraste lingüístico-cultural. Valencia, 13 de septiembre de 1994.

Fortuño LloRens, SANTIAGo (1992). Primera generación poética de postguerra. Estudio y antología. Prólogo de Leopoldo de Luis. Madrid: Ediciones Libertarias.

- (1995). «Carlos Bousoño: El ojo de la aguja o la festividad de la palabra», en Ínsula, 582-582, junio-julio, pp. 19-20.

17 En marzo de 1993, en el Aula de la Tertulia Hispanoamericana. La cita aparece en la contracubierta de la edición de El ojo de la aguja empleada en la realización del presente trabajo. Véase Bousoño (1993). 